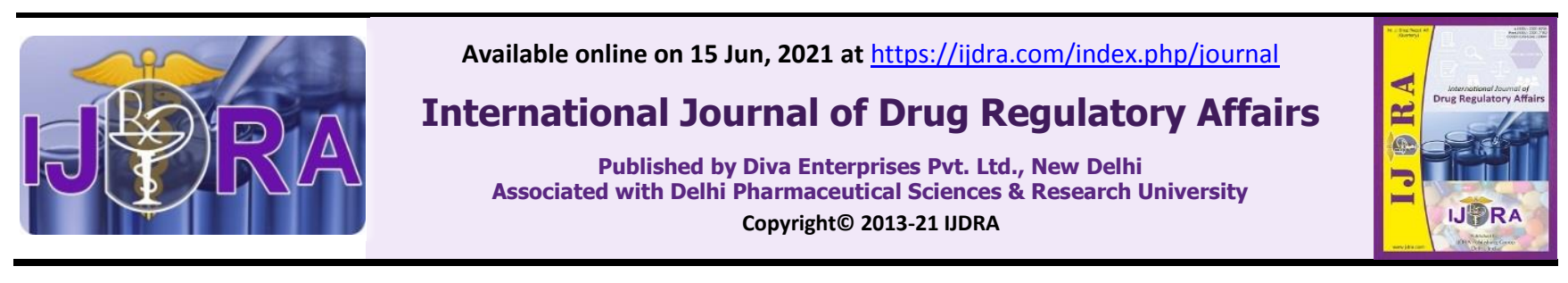

Review Article

Open $\odot_{\text {Access }}$

\title{
Indian Active Pharmaceutical Ingredient (API) Industry- An overview on Challenges, Opportunities \& Regulatory prerequisites
}

\section{Shefali Singh* and Harvinder Popli}

Department of Regulatory Affairs, School of Pharmaceutical Sciences, Delhi Pharmaceutical Sciences and Research University, New Delhi, India

\begin{abstract}
Active pharmaceutical ingredient is a chemical compound which is most important raw material to formulate a finished pharmaceutical medicine and has a pharmacological effect. India has a long history of being heavily dependent for these raw materials on China due to one major reason i.e. Low manufacturing cost. But overdependence of APIs imports from China brought various liabilities to India including supply chain disruption and price hikes during pandemic, leading to shortage of various important APIs/KSMs. This COVID 19 widespread has solidly put the center of our country on being "Atma Nirbhar". And this activity had brought out the strengths, market patterns and opportunities in five divisions counting Healthcare, which are basic from country's point of view. In view of changing geo-political situation and recalibrated trade arrangement, it is crucial that India become self-reliant within the generation of APIs and KSMs, which is why decreasing the Import reliance for Active pharmaceutical ingredients (APIs) \& Key starting materials (KSMs) particularly from china has been focused upon with the assistance of productive linked incentive scheme (PLIS) passed by Department of pharmaceuticals, Government of India to thrive Indian API industry.
\end{abstract}

Hence, this review highlights the current state of Indian API industry, evaluates challenges, opportunities give suggestions for moving forward for self-sufficiency of APIs as well as centers on current regulatory prerequisites for Active pharmaceutical Ingredients.

Keywords: Active pharmaceutical ingredients, Indian API industry, overdependence, PLIS scheme, API market insights, Regulatory prerequisites

Article Info: Received 21 May. 2021; Review Completed 12 Jun. 2021; Accepted 14 Jun. 2021

Cite this article as:

Singh S and Popli H. Indian Active Pharmaceutical Ingredient (API) Industry- An overview on Challenges, Opportunities \& Regulatory prerequisites. Int J Drug Reg Affairs [Internet]. 2021 Jun 15 [cited 2021 Jun 15]; 9(2):66-76. Available from: http://ijdra.com/index.php/journal/article/view/471

DOI: $10.22270 /$ ijdra.v9i2.471

*Corresponding author

\section{Introduction}

According to WHO, Active Pharmaceutical Ingredient is defined as "a substance used in a finished pharmaceutical product(FPP),intended to furnish pharmacological activity or to otherwise have direct in the diagnosis, cure, mitigation, treatment or prevention of disease, or to have direct effect in restoring, correcting or modifying physiological functions in human beings." (1) The effectiveness and safety of drugs are entirely dependent on the quality of APIs, implying that lowquality APIs can cause serious problems such as illnesses and even death. API has a direct effect on the quality and cost of pharmaceutical products. (2) India is a major player in the API market and counted among world's fastest-growing economies. The Indian API industry has progressed from being known for producing simple API molecules to becoming the preferred destination for high-value and complex API. (3) The global pharmaceutical market is valued at USD 1.2 trillion, with the API market valued at USD 182.2 billion. There are about 3,000 pharmaceutical companies and 10,500 industrial units in this sector. Despite a very strong foundation, domestic pharmaceutical companies have consistently stopped manufacturing APIs in lieu of importing APIs, which was a cheaper option with higher benefit margins on drugs, due to low benefit margins and a non-profitable industry. In 2019, India imported Rs 249 billion of intermediates and APIs, with China accounting for about Rs 169 billion. (4)

A total of 600 APIs and Drug Ingredients are imported into India, with 58 molecules coming exclusively from China. Due to the availability of lowercost APIs from China, the pharmaceutical industry has become increasingly reliant on imports and has shifted to more productive formulations. Imports from China have been steadily increasing, and now account for around 68 percent of total imports. The API market in India was worth Rs 574 billion in 2018 and has grown at an annual rate of $8.6 \%$ to reach Rs 735 billion in 2019. By 2024, the Indian API market is expected to be worth around Rs 
1109 billion. API currently accounts for about onefourth of the Indian pharmaceutical market, with formulations accounting for the remainder. With around 1,500 units, India's API industry is highly fragmented. During 2018-19, the top 14-16 companies (which also included larger detailing firms) accounted for 16-17 percent of the total market share. According to a KPMG report, India's share of total pharmaceutical exports for bulk drugs and intermediates has declined from 42 percent in 2008 to 20 percent in 2018. In 2020-2021, India is expected to export APIs worth Rs 303 billion. The revenue generated by the export of bulk drugs is roughly one-fourth of the revenue generated by the export of formulations. (4) India had stopped producing APIs for various antibiotics, vitamins, and even steroids. Intermediate preparations such as atorvastatin, chloroquine, ciprofloxacin, cephalosporins, immunesuppressants, and others have also been discontinued in India. India has increased its imports of API from China as a result of the globalization of Indian pharmaceutical companies and the growth of mega manufacturing facilities in China. The lower production cost is a key driver for the increased import of APIs.

\section{An overview on market insights of Indian API industry}

During the forecast period, the market of Indian bulk drug Industry is anticipated to grow at an elevated rate (2020-2026). India's pharmaceutical industry lies at the third position among the largest pharmaceutical industries in the world, in context of production volume and in context of value, it is termed as the thirteenth largest in the world. The rising prevalence of chronic diseases, as well as the growing importance of generics, is two main elements driving the flourishment of Indian bulk drug market. The market is also growing due to advancements in API manufacturing and the development of the biopharmaceutical division. (5) The industry's growth has been fuelled by the adoption of international standards and the establishment of largescale manufacturing plants within the country. The number of FDA-approved plants in India is the highest in the world (665),), accounting for 44 percent of all global abbreviated new drug applications (ANDA). The Government of India has launched a number of initiatives, including clusters and the Production Linked Incentive (PLI) scheme, to advance API (bulk sedate). The PLI scheme makes a difference by assisting domestic manufacturers with the 'Make in India' initiative. Over the last few decades, India's pharmaceutical industry has grown tremendously. In terms of volume, India supplies 20 percent of the global demand for generic drugs and more than 60 percent of the global demand for various immunizations and antiretroviral (ARV) drugs. About 57 percent of APIs on the World Health Organization's prequalified list come from the Indian region. (6)

\section{History of API imports from China to India 2012-2019 (INR crore)}

Low-quality APIs supplied by Chinese API manufacturers, on the other hand, have resulted in the recall of a number of products due to API impurity issues in recent years. Along with it, the COVID-19 pandemic has disrupted the API supply chain, resulting in a shortage of many drugs. These factors have prompted the government to promote a self-sufficiency plan in order to reduce reliance on China. The Indian government approved a production-linked scheme worth INR 6,940 crore in March 2020 to encourage domestic manufacture of essential drug intermediates and APIs, as well as a 3,000 crore scheme to promote bulk drug parks. Concerns about the quality of imported APIs from China, as well as supportive government programmes to increase domestic API production, have reduced reliance on China and are creating significant opportunities for new and existing domestic API producers. Figure 1 reflects the extent of dependency on different countries to outsource APIs/KSMs, with largest percentage of low value and high volume being sourced from China despite of proven strong chemistry skills of Indian industry. (7)

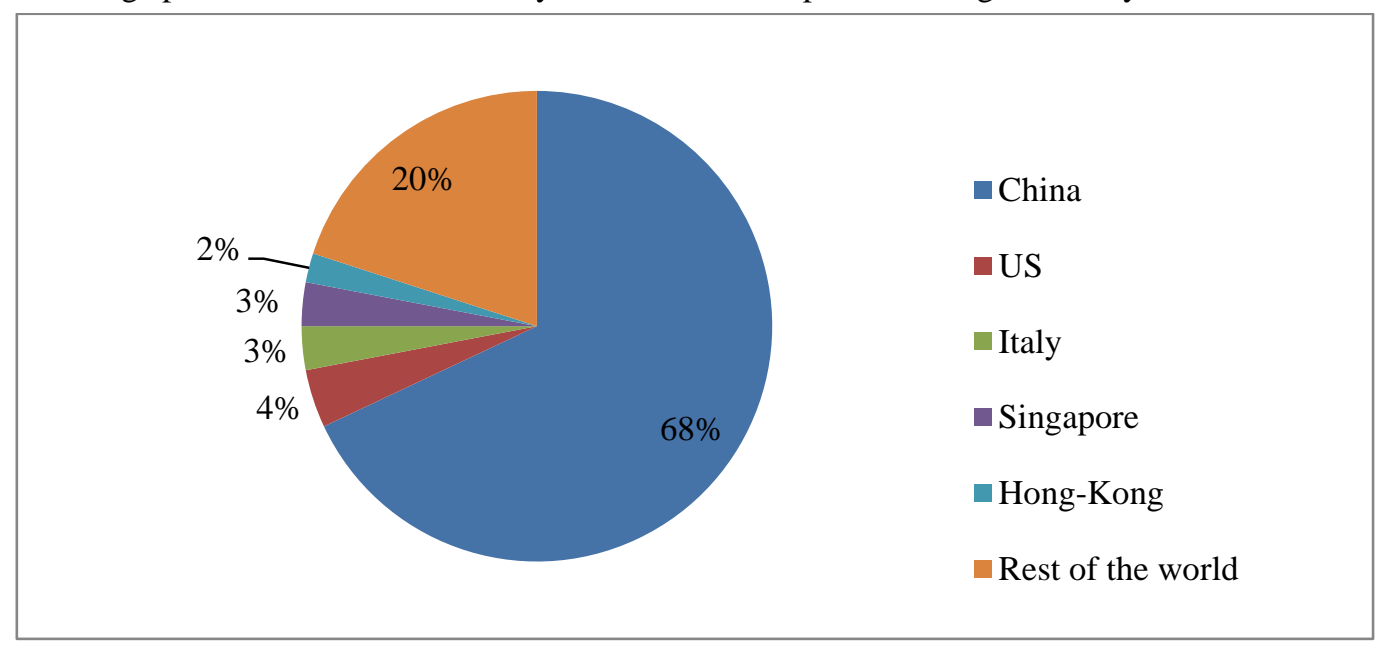

Figure 1. High dependence on China for API \& KSM Imports (7)

\section{Comparative Study of India and China $(8,9)$}

By volume of API production, China has surpassed the United States as the world leader in API production and export. Precious antibiotics like penicillins, important vitamins, antipyretics, analgesics, antihypertensives, hypocholesterolemics, and antianginals are among the APIs and intermediates that China produces in large quantities. 
Table 1. China vs. India: Manufacturing Potential for Selected APIs $(4,8)$

\begin{tabular}{lcc}
\hline $\begin{array}{c}\text { Active pharmaceutical } \\
\text { ingredients }\end{array}$ & $\begin{array}{c}\text { A Chinese firm's average } \\
\text { potential(Million tones/ } \\
\text { annum) }\end{array}$ & $\begin{array}{c}\text { An Indian firm's average } \\
\text { potential(Million tones/ } \\
\text { annum) }\end{array}$ \\
\hline Simvastatin & 500 & 150 \\
Cefexime and lactic acid & 600 & 200 \\
Pregablin & 500 & 150 \\
Gabapentene & 14000 & 3000 \\
Amoxycillin & 14,000 & 5000 \\
Losartan & 600 & 200 \\
\hline
\end{tabular}

The Indian bulk drug (API) industry is worth INR 800 billion in 2020 and is anticipated to grow at an annual rate of 8.57 percent to INR 1,307 billion by 2026 .

The Chinese bulk drug (API) industry is worth INR $\sim 1000$ billion in 2020 and is anticipated to grow at an annual rate of 6.49 percent to INR 1,431 billion by 2026 .

\section{Support for Chinese policies (10)}

China has strategically implemented a number of programmes and initiatives, including policy and infrastructure reforms, to help the pharmaceutical and related raw material industries gain traction and scale. This entails fostering innovation across the value chain, shortening approval processes, improving efficiencies, and delivering essential utilities at reduced rates.

\section{Faster approval process}

By joining the 'International Council for Harmonisation of Technical Requirements for Pharmaceuticals for Human Use (ICH),' the Chinese government improved its integration into the international bulk drug market and streamlined its regulatory procedures to meet international standards This move paved the way for more foreign investment and cooperation in China's bulk drug companies. The Chinese government has made significant investments in biologics and biosimilars, both of which are nextgeneration drugs. In recent years, the Chinese government has spent around USD 1.6 billion on new drug growth, Adoption of Trade-Related Aspects of Intellectual Property Rights (TRIPS)-compliant intellectual property (IP) rules and regulations, as well as increased administrative capacity in IP offices, to expedite patent application review. China has developed a 'Thousand Talents Plan' to attract 50,000 $\mathrm{PhDs}$ from around the world through research funding, as well as a collaborative research ecosystem in which returning talent will form major alliances between multinational corporations, universities, and other businesses - A national emphasis on $\mathrm{PhD}$ scholars with an interest in the pharmaceutical industry. 50 - Provincial and/or local R\&D 'parks' have been established to provide economic and/or infrastructure-related benefits. Low-cost facilities, R\&D grants or subsidies, loan access, and tax benefits are all possibilities.

\section{Investing in infrastructure}

It has also expressed a strong desire to improve supporting infrastructure, such as common facilities, logistics, and continuous processing, all of which will help to boost productivity. Common utilities such as common steam supply, cooling water, chilled water, nitrogen gas, and compressed air are available in China's bulk drug parks. To provide an uninterrupted power supply and steam, coal-fired power plants with capacities of up to $250 \mathrm{MW}$ and dual power transmission lines are typically constructed. The capacity of most effluent treatment plants ranges from 50,000 to 100,000 MT per day. Companies are charged INR 30 per MT of waste water with a COD level of 500.The clusters are also close to ports and airports, allowing for better logistical support.

\section{Investor-friendly culture}

Greater transparency in central and provincial procurement processes China provides an income taxfree period for the first three to five years after commercial operations begin. A portion of the VAT tax is refunded, as is a portion of the employers' income tax. Direct price control is being phased out, and administrative price supervision is being strengthened. Electronic monitoring system for pharmaceutical products is being implemented.

\section{Support for Indian policy (11)}

India also intends to boost the production of APIs in the country. The Indian government had tasked the Katoch Committee with recommending measures to ensure the country's bulk drug self-sufficiency. The following recommendations were made by the committee in its 2015 report:

- Six large API manufacturing clusters or mega parks will be established in five to six states. These clusters would be equipped with common effluent plants, testing equipment, reliable power, and IPR management, among other things.

- Manufacturers are given cash incentives: - A 15year tax break for cluster participants and developers - If a Finished formulation is developed from a locally produced API, the government is considering exempting suppliers from the Drug Price Control Order (DPCO). - Subsidized land and other infrastructure, along with interest subsidies on bank loans (through interest subvention up to 7.5 per cent) - provided the plant is first needed to be approved by the environment ministry, API manufacturers will receive a single-window environmental clearance for all drugs. - For each product, income tax benefits are available for the first ten years from the date of launch. 
- A proposal was also submitted to provide venture capital funding to pharmaceutical SMEs with a corpus of around INR 5 billion.

\section{Technology Upgradation Assistance Scheme}

Small and medium enterprises (SMEs) in the pharma sector will get interest subventions on loans taken for technology/infrastructure development to meet WHO GMP standards under the Scheme for Development of Pharma Industry in India.

India vs. China (Cost breakdown and comparison (4)
Financing, logistics, production, and set-up costs are all included in the cost of production and breakup. Infrastructure investment, labour productivity and cost, large-scale manufacturing capacities, scale of operations, Access and cost of capital, technological capabilities, logistics facilities, land reforms and supportive government policies, among other factors, are anticipated to accelerate China to the top of the market. China's production costs are roughly $20-30 \%$ lower than India's. In comparison to China, India's raw material costs are $25-30 \%$ higher. In comparison to China, India's labour costs are $1.85 \%$ lower.

\begin{tabular}{|c|c|c|c|}
\hline Parameter & India & China & Rationale \\
\hline Electricity & & & $20 \%$ cheaper than India \\
\hline Labour cost & & & $1.8 \mathrm{x}$ lower in India \\
\hline Labour productivity & & & $1.5 \mathrm{x}$ higher than India \\
\hline Access and cost of capital & & & $8 \%$ lower than India \\
\hline Scale of operations & & & $30 \%-40 \%$ higher than India \\
\hline Government facilitation and land reforms & & & Need for better policy support in India \\
\hline Logistics infrastructure and cost & & & Logistic cost is $2 \%$ lower than India \\
\hline Availability and cost of raw materials & & & $25 \%-30 \%$ lower than India \\
\hline Technology and conversion efficiencies & & & Lack of investment and incentives in India \\
\hline Production and set-up costs & & & $15 \%-20 \%$ lower than India \\
\hline \multicolumn{4}{|c|}{ Competency Level } \\
\hline
\end{tabular}

*Source: CII-KPMG Report 2020, Ind-Ra

Figure 2. Comparison of India and China on factors of cost competitiveness for API (9)

\section{Challenges impacting Indian bulk Drug Industry} $(4,12)$

Indian bulk drug industry has great potential, but it must overcome key challenges such as limited government support, insufficient infrastructure, long environmental clearance time lines, complicated regulatory structure, price control regime, and price volatility due to high import dependence. Following discussions with industry leaders, the following key challenges have been identified:

\section{In the past, the government provided only limited assistance (12)}

The government has taken no proactive steps in terms of funding options and tax benefits, single window clearance and fast-track approvals, capital subsidies, and a budget for API clusters The Katoch committee's recommendations for improving the bulk drug industry, which were made in February 2015, have seen some progress.

\section{Inferior Infrastructure facility (12)}

Due to a lack of infrastructure support, Indian API farmers are facing higher operating costs. There aren't enough bulk drug clusters, low-cost utilities (waste management systems, steam, water, electricity, and so on), R\&D support, and skilled manpower. As of July 2019, 11 of India's 232 special economic zones (SEZs) were devoted to the pharmaceutical industry. Due to the lack of API-focused SEZs, the cost of acquiring land, setting up operations, and accessing utilities has increased.

\section{Issues with environmental clearances (4)}

The clearance process is complicated because it necessitates approvals from several agencies, including Prior Environmental Clearance from the State Environment Impact Assessment Authority; Coastal Regulation Zone (CRZ) clearance from the concerned State/Union Territory Coastal Zone Management Authority (CZMA); authorisation for the handling of hazardous waste from the State Pollution Control Board; and an assessment of the surrounding environment (MoEF \& CC). Even if companies choose Zero Liquid Discharge, they may face delays in receiving approvals and production quantity limitations.

\section{Complex approval process for setting up a manufacturing plant}

Multiple regulatory bodies set rules and guidelines for the pharmaceutical and bulk drug industries, either directly or indirectly. At the policy-making level, this multiplicity can lead to inefficiencies in resource allocation and, as a result, a split agenda. Due to different decision makers, problems relating to legislation can often take longer to resolve. With different stakeholders, the approval timelines are long (about two-three years) and voluminous (about 20-25 approvals).

Due to a high reliance on imports, price volatility exists (4) 
High reliance on a single country for imports can make us vulnerable to externalities (commodity price fluctuations, policy changes, etc.). This can lead to price volatility and supply disruptions, all of which can harm domestic industry. By tighter enforcement of environmental laws, the Chinese government took a proactive approach to address the country's pollution levels, minimize the concentration of hazardous fine particulate matter, and become compliant with international standards. As a result, 150 API suppliers in China have had to close their factories since 2018. This resulted in a 50-200 percent (short-term) increase in the cost of most widely sourced APIs and intermediates from China, depending on the product.

\section{The effect of the Coronavirus outbreak on the supply chain (4)}

Smaller companies suffered more from China's production slowdown during the coronavirus outbreak than bigger companies with diversified drug portfolios. Several pharmaceutical ingredients have increased in price, at least temporarily, for Indian drugmakers. Various potential antibiotics, such as Azithromycin, have risen in price by at least 50\% since January 2020. To address a domestic shortage of essential medicines, the Indian government has imposed export restrictions on around 26 pharmaceutical ingredients..

4. Measures or ways for reducing the dependency on others and to promote the indigenous production $(7$, 13)

The availability and cost of raw materials, technology and conversion effectiveness, maintenance, manpower, infrastructure, cost of capital, and logistics are just a few of the factors that influence operations in the pharmaceutical industry. India must reduce the cost of all of these variables. For long-term viability and to make a mark in the global market, India needs to reduce costs by $20 \%$ to $25 \%$.

\section{Aggregations of Bulk drug manufacturing plants}

Companies will improve operational efficiency and decrease their dependence on imports by generating API manufacturing clusters. Also with the Provision of essential facilities such as training centres, logistic centers, industrial wastewater treatment plant, testing facilities and required $R \& D$ centres, all backing up with sufficient and cost-effective power supply within a designed facility can be harnessed by various pharmaceutical companies to incite the production of APIs. Furthermore, operations at the current clusters in few states needed to be expedited.

\section{Using policy support to encourage domestic production}

A set of production-related policy schemes must be implemented by the government that include incentives for environmental, quicker land and utility clearances, among other things through a single window. Simultaneously, land power and water supply must be made widely accessible at low prices, which is currently a significant competitive disadvantage. With assistance of policy support by government of India, for Greenfield plants and different investments in order to uplift the production of 41 products including 53 essential APIs which are highly imported from China, including antiTB drugs, anticonvulsants, antiretroviral, antibiotics (tetracycline, neomycin, azithromycin, norfloxacin, etc.) cardiovascular, vitamins (vitamin B1, B6, B12, etc.), hormones, and steroids, is a major step forward in this respect.

\section{Economic support}

Along with policy support, financial assistance in the form of subsidized loans, partial/full waivers, capital subsidies, tax and duty exemptions, credit system, affordable interest rate for capital goods imports are among several necessary inputs needed to boost domestic API production.

\section{Using less expensive raw materials with good quality}

The cost of raw materials from the petrochemical industry is another advantage that India needs to achieve. We need to work on lowering raw material costs in India by bringing in a sufficient number of petrochemical companies. We have the biggest Pyridine manufacturing plant in North India, but we only use 35 percent of its capacity. Companies tend to purchase from outside sources because they save money. India should consider how to become more self-sufficient in basic raw materials

\section{Utilization of Green Technology (8)}

The API industry has been recognized by the Pollution Control Board as one of India's 18 most polluting industries, necessitating the use of greener technologies. For illustration, Shri Gopinathan .C, Associate professor of Biotechnology at University of Calicut has discovered a new process for effective production of penicillin from waste(orange peels and pulp) generated during production of orange juice. This technology not only cost effectively produces the antibiotic penicillin, but also is environmental friendly. The process technology used is solid state fermentation/microbial fermentation.

\section{R\&D on low-cost API production technology (7)}

The government, for its part, must support industryacademic collaboration by providing appropriate grants and scholarships. Native med-tech start-ups should be rewarded for exploiting cutting-edge technologies like $3 \mathrm{D}$ printing, artificial intelligence, smart sensors, and robotics

\section{Opportunities for Indian Active Pharmaceutical Ingredients Manufacturers (14)}

\section{Alternate sourcing and self-sufficiency in APIs / intermediates (6)}

Maintaining Indian firm's competitiveness and ensuring supply security for the local market would require ensuring India's self-sufficiency in API/intermediates. Investing in next-generation APIs will help India pharma stay on the cutting edge of these technologies and set itself apart from the competition. While indigenous skills and capacities ramp up, the industry should look at alternative sourcing regions 
(such as Vietnam and Indonesia). The government should play a critical role in assisting the sector in achieving API/intermediate self-sufficiency. It may look into establishing three to five dedicated API/intermediate clusters across the country. It could go even further by providing extra incentives for players to invest in $R \& D$ in these areas and also provide grants to academic institutions and public-sector organisations to invest in this area, as well as establish dedicated research centres.

\section{Recent initiatives taken by the government (4, 15-17)}

\section{"AatmaNirbhar Bharat Abhiyaan Package"}

The government announced a package worth INR 9,940 crore for the bulk drugs industry in March 2020, in order to increase domestic production and exports. The Cabinet has approved INR 3,000 crore over the next five

Table 2. Production Linked Incentive (PLI) Scheme to Encourage Indigenous Production of Essential KSMs, Drug Intermediates, and APIs

\begin{tabular}{|l|l|}
\hline Outline & $\begin{array}{l}\text { For the next six years, qualifying producers of } 41 \text { goods will receive a financial } \\
\text { reward based on incremental sales over base year FY2019-20. }\end{array}$ \\
\hline Benefits & $\begin{array}{l}\text { For the next six years, qualifying producers of } 41 \text { goods will receive a financial reward } \\
\text { based on incremental sales over base year FY2019-20. }\end{array}$ \\
\hline INR 6,940 Crore (US\$ 938 Million)
\end{tabular}

In the wake of the Coronavirus, the government is speeding up the Green Nod process for bulk drug project. (19)

The Indian government has agreed to speed up the environmental clearance process for projects proposing bulk drug projects involving bulk drugs and bulk drug intermediaries so that they can commence as soon as possible. The issue has been resolved, according to a memo issued by the Environment Ministry's office, and will be implemented immediately. The government has also established a committee to address the issue of drug shortages caused by trade restrictions caused by the spread of the Coronavirus. The committee stated in its report that the current stock of APIs may only be useful for 2-3 months in order to manufacture formulations. To avoid a shortage in India, the government has already put a halt to the export of certain medicines such as antibiotics.

\section{Current regulatory requirements for Active Pharmaceutical Ingredients (20)}

\section{Authorisation of API}

The API information must be included in the registration document for the medicinal product itself in India. However, bulk manufacturers should file separate dossiers for APIs (and in the US, also for intermediates) with the authorities as "supporting information" to the registrations of medicinal products in the United States, the EU Member States, and many other countries. These dossiers, which typically contain years to support bulk drug parks and fund common infrastructure facilities at three of them. A Production Linked Incentive (PLI) scheme to promote domestic manufacture of essential key starting materials (KSM), drug intermediates, and active pharmaceutical ingredients has also been approved by the government (APIs). For a period of six years, eligible manufacturers of 53 identified essential bulk drugs will receive a financial incentive based on incremental sales over the base year (2019-20). Despite the fact that the initiatives have been approved, their timely implementation is critical. Table 2. provides insights of schemes in Atma nirbhar bharat abhiyaan for promotion of indigenous manufacturing. $(17,18)$ detailed - and thus confidential - information on the manufacturing process, are referred to as "Drug master files" in most cases. A Drug Master File (DMF) is a document that contains all of the details about an Active Pharmaceutical Ingredient (API) and submitted by the API's manufacturer to the regulatory authority. A typical DMF includes accurate and full information on its chemistry, manufacturing, quality controls, stability, packaging, and current GMP condition. But there has been no significant guidelines generated by Indian regulatory authority i.e. CDSCO (Central drug standard control organization) for DMF filling. Hence India has been following US format of DMF filling for the submission of confidential data regarding drug substance (API) to CDSCO

\section{The Function of Drug Master File (DMF)}

The DMF system was designed to enable suppliers to directly share product details with regulatory authorities for the analysis of applications of pharmaceutical firms involving the material sent by supplier. DMF allows the parties to reference the material without any disclosure of the content of this document to those parties and keeps the intellectual property right protected as well.

DMF can be submitted to support following types of applications:

- $\quad$ New drug application (NDAs)

- Abbreviated New Drug Application (ANDAs) 
- Investigational New drug Application (INDs)

- Biological Licence application(BLAs)

- Another DMF

- Export Applications

Also, A DMF is NOT used as a substitute for an IND, NDA, ANDA, or Export Application. It has neither Table 3. Type of DMF's (20) approval nor disapproval. Only when the technical contents of a DMF are cited in other regulatory filings as discussed before, then they are reviewed. After a review of the DMF, an inspection at an API manufacturing site may be requested by regulatory authority.

\begin{tabular}{|l|l|}
\hline TYPE 2 & $\begin{array}{l}\text { Information based on chemistry, manufacturing and controls of Drug substance, Drug Substance } \\
\text { Intermediate, Drug product and Material used in their preparation }\end{array}$ \\
\hline TYPE 3 & $\begin{array}{l}\text { Information regarding Packaging } \\
\text { TYPE 4 }\end{array}$ \\
\hline TYPE 5 & $\begin{array}{l}\text { Information based on Excipients (colorant, flavor, Essence, or Material) } \\
\text { types.(sterile manufacturing plant, toxicology etc) }\end{array}$ \\
\hline
\end{tabular}

*DMF Type 1 gives data regarding plant information such as manufacturing operations and facilities and not applicable now

\section{Prerequisites for DMF Registration}

The term "drug substance" is sometimes used to illustrate a pharmaceutical ingredient. The registration of active substances occurs in tandem with pre-market approvals such as the NDA and ANDA. That means API does not need a separate registration process. API manufacturers are required to send data compiled in a DMF. The regulatory authority examines the data and assigns a unique DMF number. And when a finished product manufacturer applies for approval from the regulatory authority, they include the DMF of the drug substance as a supporting document in applications such as NDA and ANDA (Generic).

\section{Regulatory Requirements for the submissions}

DMFs submitted must be in ENGLISH. In case of other language, a certified English translated version must be included.

A DMF encloses the following documents:-
a) Transmittal Letters
b) Administrative Information
c) Drug master File contents

-Quality information according to each Type. In case of active pharmaceutical ingredient (Drug substance), Type II is taken under consideration

\section{Transmittal letters}

\section{Original Submission}

a) Identification of original submission: Type and subject of DMF as classified by FDA.

b) Identification of the application (To which the DMF is proposed to support): Name and address of sponsors, applicants/Holders and documents numbers.

c) Statement of commitment: Signature of the Holder or authorized representative and title of signer typewritten.

2. Amendments, when required

\section{Administrative information}

1. Original submission includes Name and address of the following
a) DMF Holder
b) Corporate Headquarters,
c) Manufacturing Processing Facility,
d) agent(s) if any
e) contact for FDA correspondence.

Also, the responsibilities of each personnel involved in manufacturing facility are Listed along with Statement of commitment.

\section{Amendments, when required}

\section{Drug Master File Contents}

PART 1: Type II DMF for drug substance (Quality information based on Module 3 of ICH CTD format). The general technical content is as followed. (21)
a) Manufacturing Sections
b) Quality operation and controls
c) Impurities
d) Validations
e) Stability data
f) Packaging and labeling

\section{PART 2:- General information and Suggestions}

\section{Environmental assessment}

DMF must include the statement of commitment from the holder of DMF, stating the compliance with all local applicable environmental laws and regulations.

\section{Stability}

Stability study design, protocol, commitment, interpretation and other information should be attached, if applicable.

\section{PART 3:-Authorization to refer to DMF}

Letter of Authorization: If the DMF is in paper format, all Letters of Authorization (LOAs) should be sent in two copies. The name of the particular item being cited, 
as well as the date on which information about that item was submitted, should be specified in LOAs. The letter of authorization should not be referred to as a letter of access. Even if the DMF holder and the approved party are the same company, a LOA is required.

Statement of Right of Reference: Submission of a Letter of Authorization by the recipient, along with a copy of the LOA and a declaration of right of reference.

Critical GMP Compliance: Although the processing of APIs is similar to the production of chemicals in certain ways, APIs are an important part of pharmaceuticals and must be subject to stringent controls over possible contaminants and cross-contaminants. As a result, the construction of an API facilty must avoid contributing to any possible API pollution. (21) With the fact that critical GMP compliance must be maintained, the guidelines to be followed in India are as the following:

In India's revised Schedule $M$ of the Drug and Cosmetics Act, GMP specifications for API are also listed. Since 2005, API manufacturers in India have been required to meet the requirements outlined in Schedule M. (22)

Schedule M, India (22): The Drugs and Cosmetics Rules (1945) regulate the manufacture, import and distribution of drug products (drugs) in India, enclosing different schedules presenting respective guidelines. Schedule M under Drug \& Cosmetics rules, 1945 states that the pharmaceutical manufacturing unit in India , holding licence to manufacture drugs must adhere to the GMP criteria outlined in the given guidelines. Schedule $M$ included the information regarding premises, warehouse area, production area, Quality Control area, manufacturing operations and controls, equipment, sanitation, documentation, master formula record, validation. Etc. It is divided in to 2 parts - Part I with further classification into part IA, part IB, part IC, part ID, part IE, part IF, and Part II .altogether these are the eight sections of the Indian GMP regulations. GMP for premises and materials are covered in Part I and Requirement of plant and equipment are covered in Part II. Focusing on Part I, There are 29 chapters in all. All the parts except Part $1 \mathrm{~F}$ cover basic specifications for the manufacture of various dosage forms in terms of facilities, equipment, methods and personnel and Buildings and structures, services, equipment, controls, and containers are all included in Part $\mathbf{~ F}$ [specific requirements of premises, plant and materials for manufacture of active pharmaceutical ingredients (bulk drugs)], which covers basic specifications for the manufacture of APIs. (23)

Apart from Schedule M for GMP consideration, the universally followed guideline of ICH Q7 is also taken into account for good manufacturing practice for drug substance.

ICH Q7:- Good Manufacturing practice guide for Active Pharmaceutical ingredients (APIs) $(24,25)$

The objective of this guideline(Q7) by ICH is to provide direction to the manufacturers regarding GMP standards of Active pharmaceutical ingredients under designated system for managing and maintaining the utmost quality throughout. It includes the API manufactured by either of the following types
a) Chemical manufacturing
b) Extraction process
c) Derivation from natural sources like animals, plants etc.
d) Communition
e) Biotechnology fermentation or cell-culture
f) Or combination of processes.

\section{Discussion and Analysis}

Pharmaceutical organizations and the government of India showed concerned about the uncertainty of the Indian pharmaceutical supply chain as outsourcing from the manufacturing facilities in China are stopped in order to stop the coronavirus disease 2019 outbreak. (26) This step came with the realization about the extent of dependency on China for various APIs/KSMs and in this emergency situation, this over-dependency brought out the various major negative effects like disruption in supply chain, price hikes or shortage of pharmaceuticals.

Hence, Innovative business models for drug price regulation and local manufacturing costs should be established for a competitive market and a rapid growth rate, according to the scenario of API industry prospects, which is very much required of the hour. Figure 4. Depicts the key recommendations in order to thrive the Indian pharmaceutical industry. (27)

In the case of the recent coronavirus outbreak, it has the ability to interrupt critical drug holdings, causing price fluctuations and eventually leading to a situation where patients' medications are unavailable.

It's past time to resurrect our domestic API industry, which has been severely harmed by policies such as tighter pollution control standards, the introduction of DPCO (2013), the full collapse of the indigenous fermentation industry and lower import duties. (28)

Figure 3. Shows the application of the guidance to the shaded steps and does not apply on the steps before the introduction of API starting material

Indian regulators authored Indian GMP specifications in Schedule $M$ of the "Drugs and Cosmetics Laws" from a regulatory standpoint. Unlike the ICH Q7, which only addresses APIs, the GMP regulations in India do not differentiate between GMP for medicinal products and GMP for APIs, with Part 1-F covering API manufacturing. Several revisions to Schedule M have since been adopted, although others are also in the development. To provide a level playing field for Indian manufacturers, regulatory agencies are promoting the strategy of harmonising Schedule M with the ICH / PICS. Simultaneously with the review and adaptation of Schedule $\mathrm{M}$, it is recommended that the Indian inspection agency's GMP inspection norms be reviewed and harmonised with global norms to give the Indian manufacturer the required boost on the global stage. (29) 


\begin{tabular}{|c|c|c|c|c|c|}
\hline \multirow{2}{*}{$\begin{array}{l}\text { Category of } \\
\text { manufacturing } \\
\text { Chemical } \\
\text { manufacturing }\end{array}$} & \multicolumn{5}{|c|}{ Stringency of applicability of this guidance in API manufacturing in colored stages. } \\
\hline & $\begin{array}{l}\text { Production of } \\
\text { the API starting } \\
\text { material. }\end{array}$ & $\begin{array}{l}\text { Introduction of } \\
\text { the API starting } \\
\text { material into } \\
\text { process. }\end{array}$ & $\begin{array}{l}\text { Production of } \\
\text { intermediate(s) }\end{array}$ & $\begin{array}{l}\text { Isolation } \\
\text { and } \\
\text { purification }\end{array}$ & $\begin{array}{l}\text { Physical } \\
\text { processing and } \\
\text { packaging }\end{array}$ \\
\hline $\begin{array}{l}\text { API derived from } \\
\text { animal sources }\end{array}$ & $\begin{array}{l}\text { Collection of } \\
\text { organ, fluid, or } \\
\text { tissue. }\end{array}$ & $\begin{array}{l}\text { Cutting, mixing } \\
\text { and/or initial } \\
\text { processing }\end{array}$ & $\begin{array}{l}\text { Introduction of } \\
\text { the API } \\
\text { starting } \\
\text { material into } \\
\text { process. }\end{array}$ & $\begin{array}{l}\text { Isolation } \\
\text { and } \\
\text { purification }\end{array}$ & $\begin{array}{l}\text { Physical } \\
\text { processing and } \\
\text { packaging }\end{array}$ \\
\hline $\begin{array}{l}\text { API extracted } \\
\text { from plant } \\
\text { sources }\end{array}$ & $\begin{array}{l}\text { Collection of } \\
\text { plants }\end{array}$ & $\begin{array}{l}\text { Cutting and } \\
\text { initial } \\
\text { extraction(s) }\end{array}$ & $\begin{array}{l}\text { Introduction of } \\
\text { the API } \\
\text { starting } \\
\text { material into } \\
\text { process }\end{array}$ & $\begin{array}{l}\text { Isolation } \\
\text { and } \\
\text { purification }\end{array}$ & $\begin{array}{l}\text { Physical } \\
\text { processing and } \\
\text { packaging }\end{array}$ \\
\hline $\begin{array}{l}\text { Herbal extracts } \\
\text { used as API }\end{array}$ & $\begin{array}{l}\text { Collection of } \\
\text { plants }\end{array}$ & $\begin{array}{l}\text { Cutting and } \\
\text { initial extraction }\end{array}$ & & $\begin{array}{l}\text { Further } \\
\text { extraction }\end{array}$ & $\begin{array}{l}\text { Physical } \\
\text { processing and } \\
\text { packaging }\end{array}$ \\
\hline $\begin{array}{l}\text { API consisting of } \\
\text { comminuted or } \\
\text { powdered herbs }\end{array}$ & $\begin{array}{l}\text { Collection of } \\
\text { plants and/or } \\
\text { cultivation and } \\
\text { harvesting }\end{array}$ & $\begin{array}{l}\text { Cutting } \\
\text { /comminuting }\end{array}$ & & & $\begin{array}{l}\text { Physical } \\
\text { processing and } \\
\text { packaging }\end{array}$ \\
\hline $\begin{array}{l}\text { Biotechnology } \\
\text { fermentation/cell } \\
\text { culture }\end{array}$ & $\begin{array}{l}\text { Establishment of } \\
\text { master cell bank } \\
\text { and working cell } \\
\text { bank }\end{array}$ & $\begin{array}{l}\text { Maintenance of } \\
\text { the working cell } \\
\text { bank }\end{array}$ & $\begin{array}{l}\text { Cell } \\
\text { culture/fermen } \\
\text { tation }\end{array}$ & $\begin{array}{l}\text { Isolation } \\
\text { and } \\
\text { purification }\end{array}$ & $\begin{array}{l}\text { Physical } \\
\text { processing and } \\
\text { packaging }\end{array}$ \\
\hline $\begin{array}{l}\text { "Classical" } \\
\text { fermentation to } \\
\text { produce an API }\end{array}$ & $\begin{array}{l}\text { Establishment of } \\
\text { cell bank }\end{array}$ & $\begin{array}{l}\text { Maintenance of } \\
\text { cell bank }\end{array}$ & $\begin{array}{l}\text { Introduction of } \\
\text { cells into } \\
\text { fermentation }\end{array}$ & $\begin{array}{l}\text { Isolation } \\
\text { and } \\
\text { purification }\end{array}$ & $\begin{array}{l}\text { Physical } \\
\text { processing and } \\
\text { packaging }\end{array}$ \\
\hline
\end{tabular}

Source:-ICH Q7 guideline

Figure 3. Applicability of ICH Q7 Guideline (25)

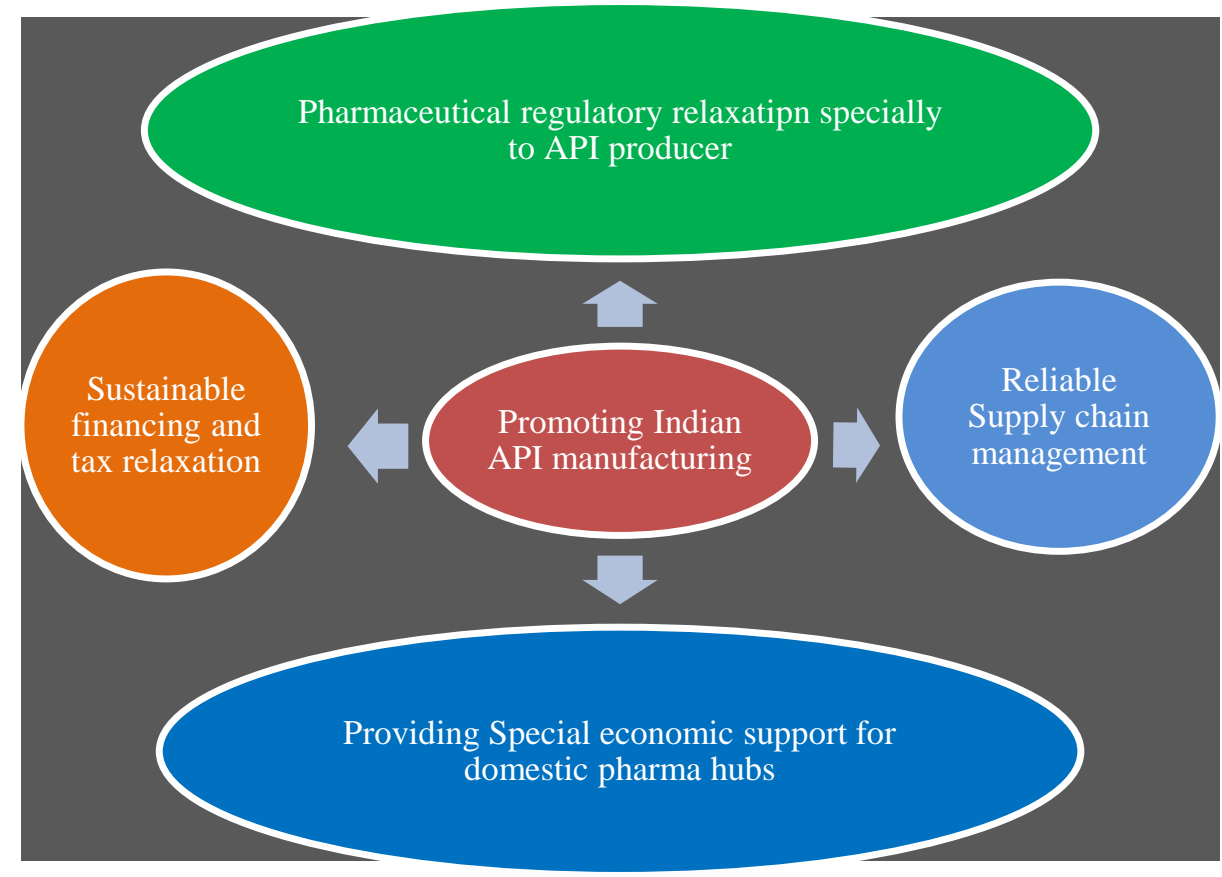

Figure 4. Key Recommendations 


\section{Conclusion}

India is one of the world's top destinations for bulk drug production. Despite its global prominence as a major source of intermediates and APIs, India's bulk drugs and pharmaceutical industry is heavily reliant on imports for many key intermediates and APIs, and China's export trade is becoming increasingly competitive. According to this analysis, a unified vision for the API sector, the resolution of internal policy and bureaucracy problems, and the concentrated implementation of identified actions would allow the pharmaceutical industry to scale up to an even higher growth trajectory.

\section{Acknowledgements}

We would like to thank Delhi Pharmaceutical Sciences and Research University, New Delhi and International journal of Drug regulatory affairs for all the support and motivation to write this manuscript.

Financial Disclosure statement: The authors received no specific funding for this work.

\section{Conflict of Interest}

The authors declare that there is no conflict of interest regarding the publication of this article.

\section{References}

1. World Health Organization. Definition of Active pharmaceutical ingredient [Internet]. Geneva: WHO; 2011 Jul [cited 2020 Oct 12] Available from: https://www.who.int/medicines/areas/quality_safety/qual ity_assurance/DefinitionAPI-QAS11-426Rev108082011.pdf

2. Good manufacturing practice Ukraine (UA). Active Pharmaceutical Ingredients [Internet]. Ukraine:gmpua; 2018 [cited 2020 Oct 22]. Available from: https://gmpua.com/API/index_en.html

3. Global Market Estimates, Indian API Industry - Market Insights [Internet]. India:global market estimatescom; 2020 May 20 [cited 2020 Nov 11]. Available from:https://www.globalmarketestimates.com/marketreport/india-api-industry---market

4. Technology information, Forecasting and assessment Council (TIFAC). Active pharmaceuticals ingredients: Status, Issues, Technology Readiness and challenges [Internet]. India:tifac; 2020 Jul 10 [cited 2020 Nov 14]. Available from:https://tifac.org.in/images/pdf/2020papers/API_Report_Released_on_July_10_2020.pdf

5. Confederation of Indian Industry [CII] in paid partnership with KPMG. Indian API Industry - Reaching The Full Potential [Internet]. India: cii; 2020 Apr 22 [cited 2020 Nov 21]. Available from: https://www.cii.in/PublicationDetail.aspx?enc=swL3yNI PL0AFuvDG0sBN7B3wn5Ja6Tk6tm/uEMPcN0k=

6. Federation of Indian Chambers of Commerce and Industry(FICCI).A white paper on Trends \& Opportunities for Indian Pharma [Internet]. India: ficci; 2018 [cited 2020 Nov 21]. Available from: http://ficci.in/spdocument/22944/india-pharma-2018ficci.pdf

7. Market insight, a subdivision of Orion market research (OMR). India Active Pharmaceutical Ingredient (API) Market [Internet]. India: marketinsight; 2020 Aug 12 [cited 2020 Dec 14].Available from: https://marketinsight.in/industry-reports/pharmaceuticalindustry-in-india

8. Sandhu G. Express pharma. Making India self-sufficient [Internet]. India:expresspharma; 2020 Aug 28 [cited 2020 Dec 20]. Available from:

https://www.expresspharma.in/making-india-selfsufficient/

9. Munde K. India Ratings\& Research: A fitch Group company. Market Wire- US API supplies to Improve: China Dependence for Raw material to remain High [Internet]. India: indiaratings; 2020 Jul 27 [cited 2020 Dec 21]. Available from:

https://www.indiaratings.co.in/PressRelease?pressReleas $\mathrm{eID}=51921 \&$ title $=$ market-wire\%3A-us-api-supplies-toimprove \%3B-china-dependence-for-raw-materials-toremain-high\#recent-p-tab

10. World Health Organization. China policies to promote local production of pharmaceutical products and protect public health [Internet] Geneva: WHO; 2017 [cited 2020 Dec 31]. Available from:

https://www.who.int/phi/publications/china_policies_pro mote_local_production_pharm/en/

11. World Health Organization. Indian policies to promote local production of pharmaceutical products and protect public health [Internet] Geneva: WHO; 2017 [cited 2020 Dec 31]. Available from:

https://www.who.int/phi/publications/indian_policies_pr omote_local_production_pharm/en/

12. Dhadich A. European pharmaceutical review. The covid-19 pandemic and the Indian pharmaceutical industry [Internet]. European Pharmaceutical Review; 2020 Apr 22 [cited 2021 Jan 04]. Available from:

https://www.europeanpharmaceuticalreview.com/article/ 117413/the-covid-19-pandemic-and-the-indianpharmaceutical-industry/

13. Joseph K. Express pharma. Reducing India's Import Dependence on APIs: A possible way out [Internet]. India: expresspharma; 2020 Apr 27 [cited 2021 Jan 10]. Available from:

https://www.expresspharma.in/guest-blogs/reducingindias-import-dependence-on-apis-a-possible-way-out/

14. Cadila pharmaceuticals limited. Opportunities for Active Pharmaceutical Ingredients (API) manufacturing in the Indian manufacturing Industry [Internet]. India:cadilapharma; 2020 Sep 22 [cited 2021 Jan 15] Available from:

https://www.cadilapharma.com/blog/innovation/futureof-active-pharmaceutical-ingredients-api-in-india/

15. Department of pharmaceutical, Government of India. Guidelines for the production linked incentive scheme for promotion of domestic manufacturing of critical key starting material(KSMs)/Drug intermediates(DIs)/Active pharmaceutical ingredients(APIs) in India [Internet]. India:pharmaceuticals; 2020 Oct 29 [cited 2021 Jan 15]. Available from:

https://pharmaceuticals.gov.in/sites/default/files/REVIS ED\%20GUIDELINES\%20FOR\%20BULK\%20DRUGS -29-10-2020.pdf

16. Department of pharmaceutical, Government of India. Guidelines of the Scheme "Promotion of Bulk Drug Parks" [Internet]. India:pharmaceuticals; 2020 Oct 29 [cited $2021 \mathrm{Feb} 13]$. Available from:

https://pharmaceuticals.gov.in/sites/default/files/Guideli nes $\% 20$ of $\% 20$ the $\% 20$ Scheme $\% 20$ Promotion $\% 20$ of $\% 20$ Bulk\%20Drug\%20Parks_1.pdf

17. PricewaterhouseCoopers $(\mathrm{PwC})$ in association with Nat health(Healthcare federation of India).Funding Indian healthcare-Catalysing the next wave of growth [Internet]. India: pwc; 2017 [cited 2021 Feb 20]. Available from: 
https://www.pwc.in/assets/pdfs/publications/2017/fundin g-indian-healthcare-catalysing-the-next-wave-ofgrowth.pdf

18. Sarwal R, Prasad U, Madangopal K, Kalal S, Kaur D, Kumar A et al. Investment Opportunities in India's Healthcare Sector [Internet]. India: NITI Aayog; 2021 Mar [cited 2021 Mar 31]. Available from: https://niti.gov.in/sites/default/files/202103/InvestmentOpportunities_HealthcareSector_0.pdf

19. Bhatt M. Republic world. Amid Coronavirus, Government to fast-track Green Nod process for bulk drug projects [Internet]. India: republicworld; 2020 Mar 12[cited 2021 Apr 02].Available from: https://www.republicworld.com/india-news/generalnews/amid-corona-fear-government-to-fast-track-greennod-process-for-firms.html

20. Srilakshmi C. Regulatory Requirements for Registration of API in US and EU. International Journal of Pharma and Clinical Research [Internet]. 2017 Jun [cited 2021 Apr 02]; 3(2):312-328.Available from: http://www.ijpacr.com/files/07-04-2017/30.pdf

21. ICH-International conference on harmonisation of technical requirements for registration of pharmaceuticals for human use. The common technical document for the registration of pharmaceuticals for human use: quality - M4Q(R1) [Internet]. US:ICH; 2002 Sep 12 [cited 2021 Apr 11]. Available from: https://database.ich.org/sites/default/files/M4Q_R1_Gui deline.pdf

22. Ministry of health and family welfare (Department of health),India. Schedule M-Good manufacturing practices and requirements of premises, plant and equipment for pharmaceutical products [Internet]. India: rajswasthya; 2001 Dec 11 [cited 2021 Apr 11]. Available from: http://www.rajswasthya.nic.in/Drug\%20Website\%2021. 01.11/Revised \%20Schedule\%20\%20M\%204.pdf

23. PricewaterhouseCoopers $(\mathrm{PwC})$. Reviving India's API Industry: from the viewpoint of covid-19 outbreak [Internet]. India:pwc; 2020 [cited $2021 \mathrm{Apr}$ 21]. Available from:

https://www.pwc.in/assets/pdfs/industries/pharmaceutica ls-and-life-sciences/reviving-indias-api-industry.pdf

24. Patel K and Chotai N. GMP requirements for "buildings and facilities" for API - comparison of schedule M, India and ICH guideline and approach for compliance to different regulatory expectations. An International Journal of Pharmaceutical Sciences [Internet]. 2013 Jan [cited 2021 Apr 21]; 4(1):3584-3616. Available from: https://docplayer.net/18626288-Vol-4-issue-1-jan-2013issn-0976-7908-chotai-et-al-pharma-sciencemonitor.html

25. ICH-International conference on harmonisation of technical requirements for registration of pharmaceuticals for human use .ICH-Q7 GMP guide for active pharmaceutical ingredients, Quality guidelines [Internet]. US:ICH; 2000 Nov 10 [cited 2021 May 02]. Available from: https://database.ich.org/sites/default/files/Q7\%20Guideli ne.pdf

26. Saha A, Mallik S. Impact of active pharmaceutical ingredient (API) scarcity in pharmaceutical sectors amidst covid-19 pandemic. International Journal of Pharmacy and Pharmaceutical Sciences [Internet]. 2020 Oct [cited 2021 May 10]; 12(12):22-25.Available from: https://innovareacademics.in/journals/index.php/ijpps/art icle/view/39396/24003

27. Chatterjee P. Indian pharma threatened by Covid-19 shutdowns in China. The Lancet [Internet]. 2020 Feb 29 [cited 2021 May 10]; 395(10225):675. Available from: https://dx.doi.org/10.1016\%2FS0140-6736(20)30459-1
28. Jain P, Srinath S, Khaleeli S. Pharmabiz. API for global \& Indian markets: Regulatory perspective [Internet]. India: Pharmabiz; 2015 Oct 08 [cited 2021 May 11]. Available from: http://www.pharmabiz.com/PrintArticle.aspx?aid=92390 $\& \operatorname{sid}=21$

29. Confederation of Indian Industry [CII] in paid partnership with KPMG. Indian bulk drugs industryRegaining the lost glory [Internet]. India: cii; 2017 [cited 2021 May 11]. Available from: http://ciipharma.in/pdf/API-Report-2017.pdf 